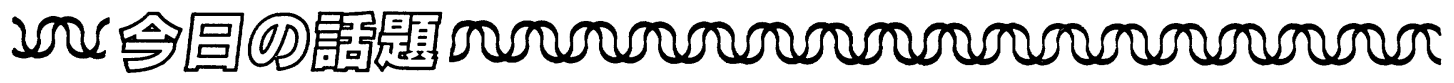 炎症の初期反応 ペプチド
}

\section{一インターロイキン2の産生を促して免疫応答を增幅. 発熱の急性期反応物質などとの関連に舆味}

炎症反応と免疫応答とは異物排除にかかわる生体防御 機構であり, 免疫系の産物である抗体や T細胞の産物 は，炎症反応に関与する種々の可溶性因子の活性化や食 細胞の機能を賦活することによって異物排除の効果をあ げていることはよく知られている，しかし，非免疫動物 飞異物刺激が加わった場合には，時間的にみて，まず非 特異的な炎症反応が発現され，この異物に抗原性がある 場合には，これに遅れて特異的な免疫応答が出現する.

したがって，炎症反応による免疫応答への影響もありそ うたが，この問題について従来あまり追求されていない.

筆者らは炎症反応が免疫応答に与える影響について観 察し，炎症初期に抗原を注射した場合にはその抗原に対 する免疫応答が増幅される現象を見いだし，この現象 が，炎症初期の局所に渗出した多核白血球によって産生 される免疫応答增幅因子によって mediate されている ことを知った(1)。抗原刺激をらけたへルパーT細胞上に は，この因子に対するレセプターが出現するため，この 炎症局所の免疫応答増幅因子は，炎症局所存在する抗 原に対する免疫応答のみを特異的に増幅することになる.

この因子は，マウスにおいては $\mathrm{p} I 9.8$ で分子量 18,000 の因子と, $\mathrm{p} I 5.4$ で分子量 21,000 の因子とから 成り，その作用機構に関する検索から，抗原刺激をらけ た Lyt $1^{+} \mathrm{T}$ 細胞に働き， $\mathrm{T}$ 細胞増殖因子インターロイ キン 2 (IL 2) の産生を促すホルモン様のペプチドであ ることが判明した ${ }^{(2)}$ ，この生物作用は，従来，マクロフ フージを in vitro で大腸菌エンドトキシンなどによっ て刺激した場合に産生されるインターロイキン 1 (IL 1）と類似している(3). マクロファージIL 1 はマウスで は $\mathrm{p} I 4.5 \sim 5.0$, 分子量 15,000 のペプチドであり, 炎症 局所の因子の 1 つが塩基性 $\mathrm{p} I$ 值を示すことを除けばよ く似ている.

しかし，炎症局所において，このような活性が認めら れる 2 ～8時間においては，その渗出細胞の 80〜95\% は多核白血球であり,この炎症早期の多核白血球を分離
し，純度 $99.0 \sim 99.9 \%$ の多核白血球について調べても， この因子を保有しており，刺激に応じて in vitro でこ の因子を遊離するので, 笑症局所では多核白血球がこの 因子を産生していることは疑いない(4). マクロファージ は， in vitro の研究によって IL 1 を産生することがよ く判明しているので，ぞのような条件下に打いて，マク ロファージにより IL 1 が in vivoにおいて作られるの かが今後の興味ある問題である.

一方, 急性炎症反応の全身現象の 1 つして, 発熱反 応はよく知られた現象であり，この発熱反応を起こす 因子として 1950 年代から内因性発熱因子 (endogenous pyrogen, EP) の研究がなされていた(5). また，急性炎 症反応の初期には，血清中の種々の物質のレベルに大き な変動がみられる，たとえば，血清中の鉄の低下，アミ ロイド蛋白 (SAA)，C 反応性蛋白 (CRP), ハプトグロ ビン, フィブリノーゲンなど, 多様な血中物質群の増加 が認められ，この現象は急性期反応 (acute phase response), またこの反応によって血中に増加する物質群 は急性期反応物質 (acute phase reactants) と呼ばれて おり，この現象を起こす因子として白血球抽出物中に存 在する leukocytic endogenous mediator (LEM) が追求 されてきた ${ }^{(6)}$.この因子を静脈注射することによって， 上述の acute phase response を再現できることはもち ろん，末梢血中への多核白血球の動員が起こることも認 められている.

上述のように，まったく独立に検索されてきたこれら の因子はいずれも炎症初期の生物反応と関連のあるこ と, これらの因子を産生させる刺激に共通性のみられる こと，因子の物理化学的性質に類似性のあることなどか ら，同じか，または類似している物質ではないかと考え られるようになった。

その根拠としては，1）ウサギの EP に対するヤギ抗 体，またはマウス細胞株由来の IL 1 に対するヤギ抗体 はいずれも他の 2 種の生物活性を吸収できること，2) 


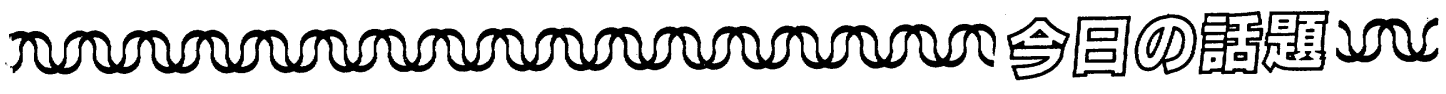

高度に精製した場合にもこれらの生物活性の分離が認め られないことがあげられている。しかし，免疫アジュバ ントの基本構造物質として知られる muramyl dipeptide (MDP)の中には, $N$-acetyl-muramyl-L-alanyl-D-glutamyl-n-butyl ester のようにウサギまたはヒトのマク ロファージに作用して Tリンパ球刺激活性，すなわち IL 1 の産生を誘導するが，発熱作用のないるのが知ら れていることから，IL 1 と EP とは異なる物質であると の考它ある.

筆者らの見いだしたウサギ多核白血球由来の 因子も $\mathrm{p} I 7.2, \mathrm{p} I 5.4, \mathrm{p} I 4.5$ の 3 種の活性分画から成るが，こ

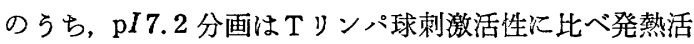
性が弱く, $\mathrm{p} I 5.4$ および $\mathrm{p} I 4.5$ 分画は $\mathrm{p} I 7.2$ 分画に比 べ約10倍の発熱活性を示すので，これらの因子は生物活 性の少しずつ異なる因子群から成っていると考えている。

これらの因子群による多彩な生物活性が他の物質, と くに内分泌系を介して起こっているのではないかという 疑問に対しては，下垂体や副腎を摘出した 動物でも， LEM を注射することにより acute phase response 様の 反応，多核白血球增多症，発熱反応のいずれもみられる こと，さらには，in vitro で肝細胞をこの因子により刺 激することにより, acute phase reactant の1つ SAA
あるいはフィブリノーゲンの産生が誘導できることなど から，この因子の直接作用であると考兄られている.

発熱作用に関しては，視床下部の発熱中枢に働いて。 その温度設定閾值を上げることによると推測されている が，培養視床下部細胞に EP を作用させた場合にプロス タグランジン産生が上昇することから，プロスタグラン ジンを介する反応ではないかと考えられている。

以上のように，個体が異物刺激にさらされた場合は， 従来よく知られている下垂体一副腎皮質系のホルモンと は別に，炎症細胞によってホルモン様のペプチドが産生 され，個体の異物への適応状態を誘導していると考えら れる．しかも，この因子が免疫応答の増幅に関与してい ることは, 生体防御反応の効率化の観点から興味深い。

1) S. Nakayama, J. Rodriguez-Pinzon, S. Nakamura \& M. Yoshinaga : Immunology, 45, 669 (1982).

2) S. Nakamura, F. Goto, K. Goto \& M. Yoshinaga : $J$. Immunol., 128, 264 (1982).

3) I. Gery \& J. L. Lepe-Zunika : "Lymphokines", Vol.9, ed. by E. Pick, Academic Press, New York, 1984, p. 109.

4) K. Goto, S. Nakamura, F. Goto \& M. Yoshinaga : Brit. J.Exp. Pathol., 65, 521 (1984).

5) C. A. Dinarello: “Lymphokines”, Vol.7, ed. by E. Pick, Academic Press, New York, 1982, p. 24.

6) R. F. Kampschmidt : J. Leukocyte Biol., 36, 341 (1984). (吉 永 秀, 熊本大学医学部免疫医学研究施設)

\section{発がん・制がん化合物のDNA一次構造·高次構造に対する 反応特異性}

\section{—DNA機能の解析, 人工制限酵素作製への利用に期待}

あらゆる生物の遺伝情報の 担い手である DNA は, Watson とCrickによって発見された 2 重らせえ構造に 扣となしく留まっているわけではなく，塩基配列に応じ てZ型構造, ステム\&ループ構造, kink, bend など, ダ イナミックな変化から微妙な変化まで樣々な変化をして いることが明らかにされつつある，B型 2 重らせん上に 生じたこれらの構造は，DNA 複製，転写，組換えなど そ扔いて，特定のタンパク質に諗識されることによっ て, 様々な DNA の機能発現に関与していると考えられ ている.このよらな塩基配列に 依存した微妙な DNA 構造の違いは, タンパク質によって認識されるだけでは なく、ブレオマイシンのような制がん抗生物質やフフラ
トキシンのよらな発がん物質によっても認識される(1).

化学発がん物質によってがん化した細胞の DNA に よって，正常細胞ががん化し，その原因ががん遗厷子の 点突然変異による活性化であったという発見は，まだ記 憶に新しい。この発見によって，化学発がんが再認識さ れるとともに，化学発がん物質や制がん抗生物質が作用 するDNA 中の部位の選択性が, 多くの研究者の興味の 対象となった，筆者らも，DNA を標的とするいくつか の物質の作用機作を，作用部位の選択性に注目して検討 を行なっている.

マイトマイシンCは，現在広く臨床で用いられている 制がん抗生物質である，その作用機作としては，生体中 


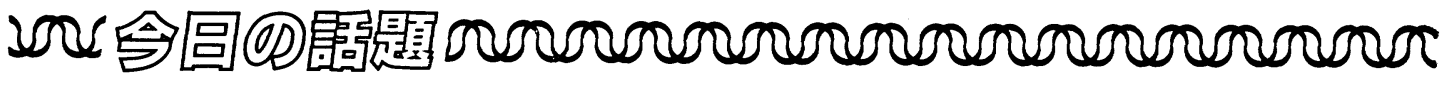

で還元されて活性型となり，DNA 中のグアニン残基と アデニン残基にアルキル化，さらには相補鎖を架橋する ことによって，DNA 合成阻害をひき起こすと考えられ ている，筆者らは，マイトマイシンがキノン骨格を有す るため，還元されることによって活性酸素を発生し， DNA に損傷を与える可能性があると考えた，そこで， 末端を ${ }^{32} \mathrm{P}$ で標識した DNA 断片を用い, MaxamGilbert 法を応用したポリアクリルアミド電気泳動法に よってマイトマイシンCの作用部位を分析した ${ }^{(2)}$. その 結果, マイトマイシンは DNA 中のすべてのグアニンと アデニン残基に均一に作用するのではなく，プリンーグ アニンーチミンという 3 塩基配列中の グアニン残基に 優 先的に作用すること，またその部位は活性酸素によると 考えられる損傷を受けて熱不安定になることが明らかと なった。

プレオマイシンは，マイトマイシンCと並んで広く用 いられている制がん抗生物質であり，1978 年に米国で 初めて塩基配列特異的な DNA 切断作用が発見されて 以来(3), 最も精力的に DNA に対する作用が研究されて いる. 筆者らは, ブレオマイシンの DNA 高次構造に対 する作用を，隣接した 3 つのステム\&ループ構造をとり らる塩基配列を持ったファージ G 4 の 1 本鎖から 2 本 鎖への (相補鎖) DNA 合成起点を用いて検討した(4). 1 本鎖 DNA を基質として用いた場合, ブレオマイシン はステムを形成する領域中の塩基配列を特異的に切断す る. 同時に, ループ領域およびステム外の領域は， 2 本 鎖 DNA を基質として用いた時には高頻度に切断される 塩基配列であっても，1 本鎖 DNA 内ではブレオマイシ ンに対して抵抗性になる。この事実は，ファージ G 4 相補鎖 DNA 合成起点領域が, 低塩濃度の緩衝液中で予 想されたステム\&ループ構造をとることとともに, ブレ オマイシンが 2 本鎖 DNA を特異的に認識することを意 味する. それに加えて, この領域が予想されていたステ ム\&ループ構造だけでなく, さらに多くの 2 次構造を含 んでいる可能性，ステム部分の 2 重鎖が普通の B 型でな い可能性なども示唆された．また，この領域中でブレオ マイシンが最も優先的に切断する部位が，DNA 複製の プライマーRNA の鋳型となるステムであり，しかも 2 本鎖切断によってそのステムを選択的に切り落としてし
まう可能性が示唆されたことは，ブレオマイシンの作用 機作を考える上で興味深い.

アフラトキシン B 1 は, ピーナッッに生えるカビが産 生し, 高い毒性と発がん性を持つことはよく知られてい る. アフラトキシンは DNA 中のグアニン残基化共有結 合し，その部位をアルカリ不安定にする．アフラトキシ ンを 2 本鎖 DNA 亿作用させた場合, すべてのグアニン 残基が均一に標的になるのではなく，前後の塩基の影響 によって優先的に作用する部位が決まる(5). また，アフ ラトキシンによって修飾された DNA は， B 型 $\rightarrow Z$ 型変 換が阻害されることも報告されている.

脂質過酸化物や 糖代謝物は, 常に 生体中に 存在し, DNA に作用し続けることによって遺伝情報の変化をも たらし，老化や発がんなどと関係があるかもしれないと 考兄られている. これら生体内低分子化合物も，DNA にアルカリ不安定な損傷を与兄，しかも標的部位は塩基 配列に依存していることがわかった(6,7).

ポリアミンは, 生物界に普遍的に存在し, DNA と相 互作用している.斉藤らは，紫外線照射下でスペルミン のアミノ基が DNA 中のチミン残基と選択的に 反応す ることを見いだした ${ }^{(8)}$.この反応は塩基配列決定に利用 できるだけでなく，現在不可能な $\mathrm{AT} \rightarrow \mathrm{GC}$ の選択的塩 基対置換を導入する方法として利用できる可能性があ る、また，紫外線によるグアニン残基の酸化をスペルミ ンが阻害するという事実は，スペルミンの生理機能を考 える上で興味深い.

現在, 多くの発がん物質, 制がん抗生物質, 新たに分 子設計された有機合成化合物などが，DNA の一次構 造・高次構造に特異的に反応することが報告されつつあ る.これらの研究の方向として, 次のようなことが考え られる。

1）発がん物質, 抗生物質の DNA に対する作用機構 を研究することによる，発がん性あるいは制がん性の解 明, 抗生物質の潜在的な能力の開発一たとえば, 最近 報告されたブレオマイシンーコバルト錯体の 光による 活 性化(9)などはその例だろう。

2）ょり効果的な抗生物質の分子設計，抗生物質の 塩基配列特異的認識作用を利用した人工制限酵素の設 計一日米で筆者らのグループを含む複数のグループが 


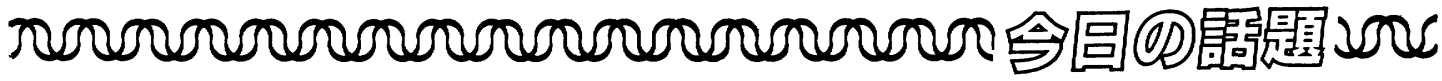

人工制限酵素を目指しているが，現在はカリフォルニア 工科大の P.B. Dervan'(10) らのグループが一歩先んじて いるようである.タンパク質が特定の塩基配列を選択的 汇認識する機構はまだよくわかっていないがこの研究 はそのモデルとしても有効と思われる.

3） DNA 構造変化の解析一一先に, DNA の様々な 機構の発現に DNA 構造の変化が関与していると述べ た．たとえば，DNA の超らせん構造が転写の促進や抑 制に関与していることはよく知られている. それには, 超らせん密度の変化に伴って生じる DNA の kink 形成 や B 型 $\rightarrow Z$ 型変換などが関与しているらしい(11)。しか し，lac オペロンの プロモーターのように 2 塩基置換 (UV 5) のみによって, 超らせん密度への依存性がまっ たく逆転してしまう機構などについてはまだまだ謎であ る.筆者らは，本稿で述べた低分子化合物の DNA 高次 構造特異的な認識作用を利用して，DNA 構造の微妙な 変化を解析することを現在試みている.

このような研究は，米国などに比べ日本であまり盛ん ではない.しかし,この研究は新薬開発、DNA 機能の
解析を含め，色々と利用価値があると筆者らは考えてい

る.さらにこの分野が盛んになることを願っている.

1) 杉浦幸雄: 化学, 38, 689 (1983).

2) K. Ueda, J. Morita \& T. Komano: Biochemistry, 23, 1634 (1984).

3) M. Takeshita, A.P. Grollman, E. Ohtsubo \& H. Ohtsubo: Proc. Natl. Acad. Sci. USA, 75, 5983 (1978); A. D. D'Andrea \& W. A. Haseltine : Proc. Natl. Acad. Sci. USA, 75, 3608 (1978).

4) K. Ueda, S. Kobayashi, H. Sakai \& T. Komano: $J$. Biol. Chem., 260, 5804 (1985).

5) K. F. Muench, R.P. Misra \& M.Z.Humayun : Proc. Natl. Acad. Sci. USA, 80, 6 (1983).

6) K. Ueda, S. Kobayashi, J. Morita \& T. Komano: Biochim. Biophys. Acta, 824, 341 (1985).

7) J. Morita, K. Ueda, S. Nanjo \& T. Komano: Nucleic Acids Res., 13, 449 (1985).

8) I. Saito, H. Sugiyama, T. Matsuura, K. Ueda \& T. Komano: Nucleic Acids Res., 12, 2879 (1984).

9) T. Suzuki, J. Kuwahara, M. Goto \& Y. Sugiura : Biochim. Biophys. Acta, 824, 330 (1985).

10) P. G. Schultz \& P. B. Dervan : Proc. Natl. Acad. Sci. USA, 80, 6834 (1983).

11) J.G. Brahms, O. Dargouge, S. Brahms, Y. Ohara \& V. Vagner : J. Mol. Biol., 181, 455 (1985).

(植田 和光, 京都大学農学部)

\section{糖尿病母体から生まれた新生児(IDM)の病理}

\section{一一解明進むインスリン受容体異常. 新生児合併症との関わリの解明が課題}

糖尿病患者が妊娠した場合, 無事子供を生むためには 適切な産科的な対策が施される必要がある，それは，糖 疗病母体では, 妊娠中毒症, 羊水過多症や糖尿病性細小 血管症の悪化などが起こりやすく, 流産, 早産, 死産が 高率であるためである。さらに, 糖尿病母体より生まれ た児 (infant of diabetic mother, IDM) においても, 体重が高值をとることが多く, 新生児低血糖症, 新生児 呼吸障害症候群, 高ビリルビン血症, 低カルシウム血症 などの新生児合併症や先天奇形などの頻度の高いことが 知られている. しかし, 近年の糖尿病治療の進歩と産科 学における母体管理や新生児ヶアの進歩により, 糖㽷病 母体よりの 出生児の 周産期死亡率は著しく低下してい る. また, 周産期にお汀る糖尿病に関する研究も進展し ており，報告もかなり蓄積されてきているここでは IDM に特有の合併症である過インスリン血症およびイ ンスリンレセプターの異常について, その周辺を含め従
来の研究経過と最近の研究について筆者らの知見も交觉 紹介することとする.

グルコースの胎盤通過様式は促進抎散 (fascilitated diffusion）によるものであるため，糖尿母体の高血糖は 胎児を高血糖環境へ置くことになる．これが IDM に認 められる障害の 基本的な原因になっていると考えられ る. IDM はしばしば巨大児となることはよく知られて 和り，体脂肪の増大や心臓の肥大などが報告されている が，高血桾はこれらをひき起こす要因と考えられる。ま た, IDM では膵島組織の hypertrophy が観察され, 過 インスリン血症が示されており, これも高血糖によるる のと考えられる.インスリンは胎盤を通過しにくく，胎 児に存在するインスリンは胎児自身が分泌したものと考 えられる. 12 週胎児の血中ですでにその存在は証明さ れており, 妊娠の間, 胎児は母体とは異なる固有の内分 泌活動をしていると思われる. 事実, その様子は種々の 


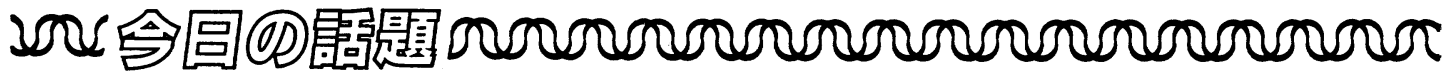

点で異なっている.

Thorsson と Hintz(1) は, 新生児の単核球のインスリ ソレセプターを成人のそれと比較し， $\left.{ }^{125} \mathrm{I}\right]$ インスリン の結合能は細胞 $10^{7}$ 個当り成人では $4.7 \%$ であるのに 対し, 新生児では $24.3 \%$ と著しく高く, さらに Scatchard 解析の結果, 受容体数は細胞当り成人で 7,100 , 新生児で 44,600 , 結合親和性はそれぞれ $2.9 \times 10^{8} \mathrm{M}^{-1}$ ， $5.9 \times 10^{8} \mathrm{M}^{-1}$ であり，成人と比べ新生児では結合能の高 いレセプターが多数存在することを観察している. そし て，胎児期のインスリンは胎児の胎内発育に何らかの重 要な役割を果たしているのではないかと推測している.

それでは，高血糖環境で育った胎児のレセプターはど のよらな変化を示すであろらか. Neufeld ら(2)は，妊娠 中に初めて血糖値に 異常を認めた母親の 児 (infant of gestational diabetic mother, IGDM) およびその単球の レセプターを正常児のそれらと比較している．それによ ると, IGDM では高体重, 過インスリン血症を示してお ク, 単球のレセプター数は細胞当り約 2.5 倍多く, 結合 親和性も増加しているという．さらに，彼らは新生児の 体重とインスリン結合量とが相関することを見いだして 吅り, これは Thorsson の提案を支持するものかもしれ ない.

一般に，多くのホルモンレセプターではホルモンレベ ルの上昇に伴いその数を減少させる down regulation が認められ，インスリンレセプターにもこの調節が証明 されている.しかし，Neufeld らによる IGDM の観察 では，インスリンの上昇とともにそのレセプターの増加 が認められており，IGDM では down regulation は成 立していない.この点について, Neufeld らはその後の 研究で，厳密にコントロールされた母親よりの IDMで はインスリンレベルもレセプター数も正常であることを 観察している(3). また，分化の過程を観察することので きる 3 T 3-L 1 preadipocyte (methylisobutylxantine と dexamethasone を加えることにより脂肪細胞へと 分化 する細胞）を用いた in vitroの実験で,インスリン自体 が自らのレセプターを誘導するという報告(4)もあり， Neufeld は胎生期のインスリンレセプターはホルモン自 体によって誘導される up-regulationを受けていると考 え, IGDM ではインスリンレベルの上昇がレセプター
の増加の一因となっていると考察している.

彼らはさらに, 他の要因として膜流動性の関与してい ることも示崚している.すなわち, Shinitzky ${ }^{(5)}$ によれ ば，膜流動性が低下した状態では膜蛋白は圧迫され，外 へ押し上げられて露出部分が増大し, 逆に流動性が増し た状態ではより埋没した配置をとるという．Neufeld $ら^{(6)}$ は, ウサギ胎仔の肺細胞膜の構成脂質を検討した結 果, 蛋白質に対するリン脂質の比は IDM で減少し, リ ン脂質に対するコレステロールの比は大きくなっている ことを認め, IDM の膜流動性は低下しており, その結 果膜表層に結合部位を露出させるレセプターが增し, イ ンスリン結合量を増加させたのであろうと推定してい る. 事実, Henson ら ${ }^{(7)}$ は, 3 T 3-L 1 adipocyte を用い た実験で，膜流動性の増加がインスリン結合量を低下さ せることを証明している。

さて, このように, IDM では過インスリン血症を示 し，インスリンレセプターが増加するという報告(8)が多 く，筆者ら ${ }^{(9)}$ もットの赤血球で IDM のレセプターの 増加する傾向を観察している. それでは，これらのレセ プターの増加にはどのような意味があるのであろうか.

言うまでもなく，インスリンは細胞の糖利用を促進させ るペプチドホルモンであり，それに対する応答性はレセ プターの数や親和性により 規定されている. したがっ て，インスリンレセプターの増加が考えられる IDM で は, 糖利用などにお汓るインスリン応答性の昂進してい ることが予期される，とこで，筆者ら(10)は，ラットを用 い, IDM の横隔膜繦織について in vitro でインスリン 応答性を検討した，しかし，グリコーゲン合成能あるい は糖の膜透過に対するインスリン応答性あるいは感受性 のいずれにも変化を観察することはできなかった，糖利 用制御におけるインスリンの調節効果は胎生期では弱い ことが知られており，筆者らの結果もこのことを示唆す るものであるかもしれない.

また，新生児呼吸障害症候群では，その要因として肺 発達の未熟性とともに肺を保護する役割を果たしている と考兄られる肺表面活性物質の減少が指摘されている. 肺発達過程でのインスリンレセプターの顕著な出現は, pseudoglandular cell が脑表面活性物質の合成を開始す るのに先だってグリコーゲンを蓄積する一時期に限られ 


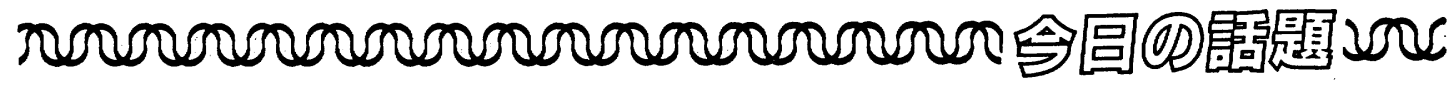

ていることが知られている．したがって，Neufeld ら(11) が IDM で認めている肺組織でのインスリンレセプター の増加は肺表面活性物質合成の遅れを意味し, 肺発達の 未熟性を示していると考兄られる.ささらに, 出生後見舞 われる低血糖に際して，IDM では正常児に比べその血 糖低下がより急速であり，その理由としては過インスリ ン血症が指摘されているが，レセプターの増大も関与し ているのかもしれない.

IDM に認められる新生児合併症の成因について，イ ンスリンレセプター異常の観点より検討を行なっている 報告をいくつか紹介したが，個々の知見は関連が そし く，成因の機序を統一的に理解するイメージを得ること は今の時点では未だ難しい上らである．それは，胎生期 に抢けるインスリンの役割の特徵あるいは特殊性が未だ 十分に理解されていないためであろうままた，糖尿病妊 婦に対する管理の進歩により種々の合併症が軽減してい る中で奇形だけは減っていないことなどああり，未解決 の重要な問題は未だ残されている. 今後のIDMに関す
る研究の進展が期待される.

1) A. Thorsson \& R. L. Hintz : New Engl. J. Med., 297, 908 (1977).

2) N. D. Neufeld, S. A. Kaplan, B. M. Lippe \& M. Scott : J.Clin. Endocrinol. Metab., 47, 590 (1978).

3) N. D. Neufeld, S. A. Kaplan \& B. M. Lippe : J.Clin. Endocrinol. Metab., 52, 473 (1981).

4) C.S. Rubin, A. Hirsch, C. Fung \& O.M. Rosen : J. Biol. Chem., 253, 7570 (1978).

5) M.Shinitzky \& M. Inbar: Biochim. Biophys. Acta, 43, 133 (1974).

6) N. D. Neufeld \& C. Lucille : Am. J.Physiol., 243, E 246 (1982).

7) B. E. Henson, A. A. Spector \& B. H. G. Ginsberg : Clin. Res., 29, 732 A (1981).

8) O.Pedersen, H. Beck-Nielsen \& J.G. Klebe : J.Clin. Endocrinol Metab., 53, 1160 (1981).

9) Y. Wako \& S. Kimura : Agric. Biol. Chem., 48, 2379 (1984).

10) Y. Wako \& S. Kimura : Agric. Biol. Chem., 48, 2669 (1984).

11) N. D. Neufeld, L. M. Corbo \& S. A. Kaplan : Pediatr. Res., 15, 1058 (1981).

（若生 昰, 木村修一, 東北大学農学部)

\section{稲のツマグロヨコバイ抵抗性機構}

\section{——電気的吸汁行動測定法により師管液の吸汁阻害が判明}

ツマグロヨコバイ (Nephotettix cincticeps Uhler) は, 稲体茎葉部に口針を刺入して吸汁掑食するが，汁液奪取 による直接加害のほか, その際に重要病害のウイルスや マイコプラズマを媒介するため, 稲作の代表的害虫に挙 げられている.

本種の防除は全面的に殺虫剤に依存しているのが実情 であるが, 省エネルギーでクリーンな理想的防除法とし て抵抗性品種の育種が進められている. 抵抗性品種上で は発育が遅れて幼虫期に死亡し，まれに羽化しても成虫 は小形化し，生殖能力を持たない，ただ，抵抗性品種は いずれも日本稲とは草型も米質も異なるインディカ稲で ある(1)ため，その抵抗性遺伝子を取り入れ，我国の稲作 に適する優良品種を作り出すことは容易でない.

また，抵抗性品種を実用化しても，それを加害できる 個体群（バイオタイプ）が優勢になり，いずれ感受性化 してしまう可能珄があることが，この方向で努力する意 欲を削いでいるかもしれない。しかし，同じ半翅目同
趐類のトビイロウンカの場合を見ると, 国際稲研究所 (IRRI) の育成した IR 26 系抵抗性品種は $2 \sim 3$ 年でバ イオタイプ 2 の発生により感受性化したが, 次に普及し た IR 36 系品種は 10 年を経過した 現在も効力を維持 し，東南アジア稲作の 主力品種となっている．1982～ 83 年にインドネシアの北スマトラ州で IR 36 を加害す るバイオタイプ 3 の発生を目撃し，この抵抗性の 崩壞 (breakdown) の始まりかと考えたが，局地的，一時的 な現象に留まった。

抵抗性品種を効率良く育種するためにる，できあがっ た品種を有効に利用するためにも，抵抗性機構の解明が 必要である. 抵抗性には機構の違ら複数の遺伝子が関与 し, 加害力を持つバイオタイプの発生に対しては, 機構 の異なる新しい抵抗性品種を導入するとか, そうなる前 に品種のローテーションを行ならとか, あるいは抵抗性 のみに頼らず総合防除の一環として利用するなと，対策 は色々考えられる。抵抗性機構が明らかになれば,バイ 


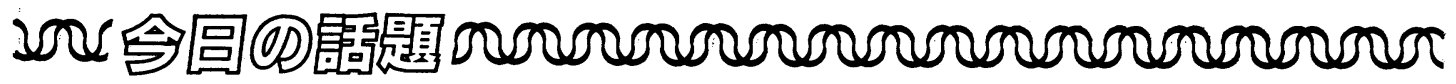

オタイプ発生問題により合理的に対応できるようになろ うし，なぜ IR 26 は容易に崩壊し，IR 36 は安定なのか という理由るわかるであろう。

ツマグロヨコバイは稲茎葉を吸汁しながら尾端より水 滴状の甘露を頻繁に排泄する. 本種の抵抗性機構の核心 に迫る手掛かりは，この甘露を採集して分析することに より得られた．抵抗性品種上での甘露は量が著しく增加 するが, 通常 $2 \%$ 程度含まれている桾類がまったく検出 されない(2,3).ところで，本種は維管束に口針を刺入し， 主に師管と導管から吸汁することが知られている(4). ま た，植物生理学によれば，師管は光合成産物の蔗糖，多 種のアミノ酸，その他色々な有機物が 転流する 場であ り，導管は根から吸収された水分を主体に，窒素の移動 体としての若干のアミノ酸やアミド，それに無機物が転 流する場である．したがって，抵抗性品種上では主栄養 源である師管液の吸汁が阻害され，代償的により多量の 導管液を吸汁するが，栄養要求は満たされず，正常な発 育を遂げることができなくなると推定された。

さて，抵抗性品種上では吸汁行動が異常化するようで あるが，植物組織中に刺入された口針の微細な行動は外 部からは観察できない，吸汁行動をダイナミックに究明 するための工夫が必要になった．そこで導入された方法 が, カリフォルニア大学の McLean と Kinsey がアブ ラムシを対象に開発した電気的な吸汁行動の測定法(5 7) (Electronic Measurement of Insect Feeding Behavior, 以下 EMIF と略記) である. EMIF は昆虫と寄主 植物の双方に電極を取り付け，両極間に交流の低電圧を かけ，口針刺入後に昆虫と寄主の間が電気的に接続され て流れる微小電流の変化を測定記録し, 吸汁行動を解析 するるのである.

この方法をッマグロヨコバイに応用するには難点があ $\eta^{(8)}$ ，装置の 改良などが 必要であったが(9)，ともかく EMIF は予想以上飞多くの吸汁行動に関する情報をも たらしてくれた.すなわち、口針の刺入，唾液を吐出し 唾液䩗（口針䩗とも呼ぶ）を形成しながらの口針の進 入, 導管からの吸汁, 口針を留めて休止, 口針の他の組 織への移動, 師管刺入後の吸汁準備過程とその後の持続 的な師管液吸汁，口針の抜去と他所への移動といった一 連の吸汁行動の進行過程が, EMIF の記録波形から読み
取れるのである(10,11).

吸汁行動の各段階がとれぞれ特徴ある波形として記録 される理由は，次のようになろう，(1)昆虫が植物体表面 と足により接触していても電流は相対的に小さく，また 口針自体はいわば絶縁体のパイプで電流を通さない，(2) 口針中を唾液か植物組織液が流れ，虫体と植物体が細い 液体の橋で連絡されてはじめて明確に電流が増大する. (3)唾液の電気伝導度が最大で, 次に師管液, 最も低いの が導管液となり， 3 者 3 様である. (4)唾液は間欠的に吐 出され, 陰圧の導管液は口部のポンプ器官の運動により リズミカルに吸入され，逆に陽圧，しかも相当高圧な師 管液はポンプ器官の助けなしになめらかに口針中へ流れ 込むなど，口針中の液の流れ方も異なる．（5液圧の高い 師管中には師管が傷ついた場合に液の流出を止める何ら かの防御機構があると考兄られ，刺入口針により継続的 に吸汁するためには，まず吸汁をこの機構に阻害されな い上うにする作業が必要なのであろう．この作業過程で 生じると推定される特異な波形が，師管刺入直後に師管 吸汁に先行して記録される。(6口針を刺入したまま休止 すると，口針中の液が途切れ，電気伝導度が降下する.

ッマグロヨコバイの吸汁行動を EMIF を用いて調べ た結果，導管吸汁中はほとんど有機物を含有しない甘露 を每分数滴以上も排泄し，師管吸汁中は数分間に 1 滴と 頻度は著しく低下するが，高濃度に糖やアミノ酸を含有 する甘露を排泄することが 確認された。師管吸汁は 10 時間以上継続することもまれではないが，導管吸汁は長 時間は続かない，ただし，吸汁の速度は導管の場合のほ らが大きいため，導管液のほうが師管液より吸汁量は大 きい. 本種は栄養的にはほとんど無価值な導管液をなぜ 多量に吸汁するのであろうか.

抵抗性品種上では，師管に口針を刺入し，吸汁準備過 程に進むが，その後の師管吸汁波形に移行することなく 数分後に口針を拔去するか，他の組織へ移動させる．抵 抗性稲上であ 導管吸汁持続時間は特に 長くはならない が，吸入運動がより活発になるため吸汁量は倍加する。

師管に口針を刺入するが吸汁しないということになる と, 抵抗性品種の師管液中には本種がまずいと感じる成 分，すなわち吸汁阻害物質が含まれると想定できる。こ の吸汁阻害物質が何かを決定するには，師管液を採取し 


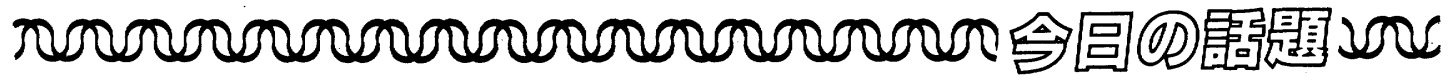

て分析するのが早道であろう，そこで筆者らは稲の師管 液を取り出す方法を確立した ${ }^{(12)}$. しかし，本種は抵抗性 品種から得た師管液も人為的に与息ると予想以上に吸汁 するため，吸汁阻害物質決定には至っていない(3)，ある いは師管内に口針を刺入した直後の師管液吸汁準備過程 に抵抗性の秘密が隠されているのかもしれない.

なお， ウンカ・ヨコバイなど同翅類に対する植物の抵 抗性では，一般的に師管からの吸汁阻害という点は共通 し, 抵抗性遗伝子の違いは，この吸汁阻害物質の違いと なっているようである.

1) T. Koshihara : Tropical Agric. Res. Series, 5, 221 (1971).

2) 河部 暹: 植物防疫, 33, 193 (1979).

3) S. Kawabe : JARQ, 印刷中.
4) 内藤 篤, 正木十二部: 応動昆, 11，50 (1967).

5) D. L. McLean \& M.G. Kinsey : Nature, 202, 1358 (1964).

6) D. L. McLean \& M.G. Kinsey : Nature, 205, 1130 (1965).

7) D. L. McLean \& M. G. Kinsey: Ann. Entomol. Soc. Amer., 60, 400 (1967).

8) S. Kawabe \& D. L. McLean : Apple. Ent. Zool., 13, 143 (1978).

9) S. Kawabe et al.: Ann. Entomol. Soc. Amer., 74, 222 (1981).

10）河部 掘：植物防疫， 33,65 (1979).

11) S. Kawabe \& D. L. McLean : Ent. Exp. and Appl., 27, 77 (1980).

12) S. Kawabe, T. Fukumorita \& M. Chino: Plant \& Cell Physiol., 21, 1319 (1980).

（河 部 暹，農林水産省九州農業試験場）

\section{脂肪性種子子葉におけるマイクロボディ変換の機構}

\section{一一解明の鍵となるか？ 不活性型力夕ラーゼの存在}

マイクロボディ (microbody) は真核生物細胞に普遍 的に存在するオルガネラである(1). 高等植物のマイクロ ボディは直径 $0.2 \sim 1.5 \mu \mathrm{m}$ の単膜構造体で, ショ糖密 度勾配遠心により密度 $1.24 \sim 1.25 \mathrm{~g} / \mathrm{cm}^{3}$ に分画され， カタラーゼが局在する顆粒と定義 づけられている(2,3). このオルガネラは生物種または組織により機能を異にす るため, いくつかの異なった名称が冠せられている. 高 等植物では，グリオキシゾーム (glyoxysome)，緑葉パ ーオキシゾーム (leaf peroxisome), 機能不明のマイク ロボディ (non-specialized microbody) の 3 種に分類さ れている，ここで述べるマイクロボディ変換とは，脂肜 性種子子葉が緑化過程に怙いてグリオキシゾームから緑 葉パーオキシゾームへと機能的に変換する現象である。

カボチャ, キュウリなど脂肪性種子子葉を暗所で発芽 させると, 黄化子葉が発達してくる.この黄化植物は従 属栄養体で, 生長のエネルギーは子葉中に貯えられた脂 肪からの糖新生によってまかなわれる．黄化植物に光を 照射すると子葉は緑化し，光合成能を獲得することにな る. これ以後, 植物は独立栄養体となる. この緑化過程 の前後に打いて，植物は形態的にも代謝的にも大きく変 化するが，この变化は細胞内オルガネラに関しても例外 ではない，前述のようにマイクロボディについていえ
ば, グリオキシゾームから緑葉パーオキシゾームへの機 能的変換が観察される.

緑化前, つまり黄化子葉に存在するグリオキシゾーム には脂肪酸 $\beta$-酸化系酵素之 TCA 回路の迂経路である グリオキシル酸回路の全酵素が局在しており、これらは 脂肪から糖への変換に 重要な役割を果たしている。一 方, 緑化した子葉中に存在する緑葉パーオキシゾームに は,グリオキシル酸回路の諸酵素はまったく認められな いが，光合成反応の 副産物であるグリコール酸の 代謝 (いわゆる光呼吸反応) に関連する一群の酵素が 局在し ている.このように, 同一細胞内においてオルガネラの 機能が大きく変換するという現象はきわめて珍しいもの である. マイクロボディが独自の蛋白質合成系を持たな いこと, 構成蛋白質が比較的単純なことなどから， マイ クロボディを用いる実験系はオルガネラ蛋白質の遺伝子 発現やオルガネラの生合成の制御機構を解明するための 貴重なモデルヶースとして注目を集めている.

ところで, 以前からマイクロボディ变換現象について は, 相反する $2 つ の$ 解釈が提唱されていた(2,3). 一つは, Trelease ら“4)により提出されていた，いわゆる “onepopulation (または interconversion)”モデルと呼ばれ るものである. 彼らは電子顕微鏡による形態観察から， 


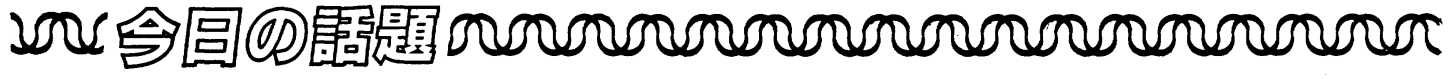

緑化の過程ではマイクロボディの顕著な分解と合成は起 こらないことを示し，グリオキシゾームは緑葉パーオキ シゾームへ直接的に変換すると主張した. 一方，もら一 つの考えとは, Beevers のグループ(5)が提唱した，いわ ゆる “two-population” モデルである. 緑化時の子葉を 用いた実験によって， ${ }^{14} \mathrm{C}$-標識コリンの緑葉パーオキシ ゾーム膜への顕著なとり达みが認められたことから，彼 らは, 子葉緑化時にグリオキシン゙ームは選択的に分解さ れ，緑葉パーオキシゾームが新たに合成されるとの考え を提出した.

その後，様々な方法により，これら 2 つの仮説を検証 する試みがなされたが，いずれも決定的な証拠を与える ことにはならなかった(2,3). そのため, この問題に対し てまったく新しい実験的アプローチが望まれていた.

このような状沇に拈いて, カタラーゼの占める立場は ニニークなものであった. なぜなら、この酵素は両マイ クロボディに局在することから，2 種のカタラーゼの蛋 白化学的比較や生合成過程を解析することによって, 上 記 2 つ仮説に関する有用な知見が得られると考えられ たからである.ささらに, 緑化過程においては, 子葉あた りのカタラーゼの活性が減少することが広く知られてい た ${ }^{(3,4)}$. したがって，この活性減少の機構についての関 心も高まりつつあった。

そこで筆者らは, 発芽カボチャ種子子葉のグリオキシ ゾーム画分からカタラーゼ（g-カタラーゼ）を精製し, その特異抗体一一抗 $\mathrm{g}$ 一カタラーゼ抗体一を調製し(6), これを用いて，g一カタラーゼと緑葉パーオキシゾームカ タラーゼ (p-カタラーゼ) を免疫化学的に比較してみ た. その結果, Ouchterlony 免疫二重拡散法と免疫電気 泳動では両カタラーゼの違いは検出できなかったが，免 疫滴定実験から， p-カタラーゼの比活性は $\mathrm{g}$-カタラー ゼに比べて 1/3〜1/4 と低いことが判明した。このよう なカタラーゼ分子の比活性の減少は子葉の緑化に伴って 生じ, マイクロボディの機能的変換に対応している(6).

この比活性の変動をさらに詳細に検討するため, $\mathrm{g}$ 一カ タラーゼと $\mathrm{p}$-カタラーゼの各々を同一の方法を用い て精製した(7). g一カタラーゼはサブユニット分子量 $55,000(55 \mathrm{kDa})$ であるが，一方 $\mathrm{p}$-カタラーゼは 55 $\mathrm{kDa}$ のサブニニットととすに $59,000(59 \mathrm{kDa})$ のサブ

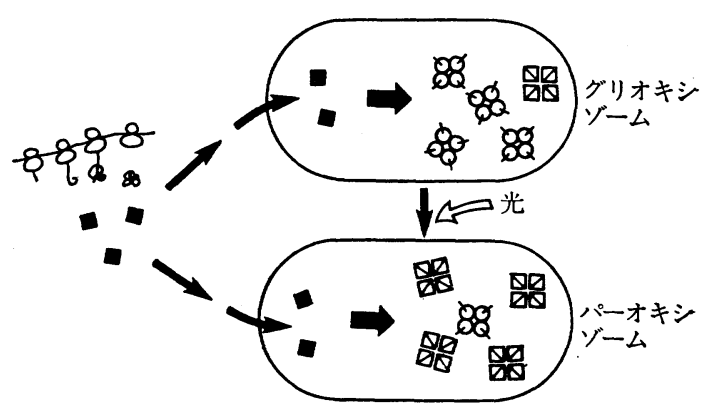

前駆体 $(59 \mathrm{kDa})$

不活性型 (59kDa,テトラマー,へムを含む)

活性型 (55kDa,テトラマー,へムを含む)

カタラーゼの不活性化とマイクロボディ变換の模式

ユニットを含んでいた. 両サブュニットとも抗 g一カタ ラーゼ抗体に対して反応性を示す. $55 \mathrm{kDa}$ ポリペプチ ドはゲル濾過により部分的ながらも $59 \mathrm{kDa}$ ポリペプチ ドと分離が 可能であり, $55 \mathrm{kDa}$ ポリペプチドの 流出パ ターンはカタラーゼ活性と完全に一致する。この結果か ら， $59 \mathrm{kDa}$ ポリペプチドは酵素活性を保持しない，不 活性型のカタラーゼであることが示唆された. そして,

（i）intact の子葉切片を用いた pulse-chase 実験か ら, $59 \mathrm{kDa}$ ポリペプチドから $55 \mathrm{kDa}$ ポリペプチドへ の変換が観察されたこと，（ii）in vitro 蛋白合成系を 用いた解析から, 両カタラーゼとも $59 \mathrm{kDa}$ ポリペプチ ドとして合成されること, (iii) S. aureus プロテアーゼ V8を用いたペプチドマップ解析により， $59 \mathrm{kDa}$ ポリペ プチドは $55 \mathrm{kDa}$ ポリペプチドのマップパターンに加え て新たな 4 個のペプチドを含むこと，などから， $59 \mathrm{kDa}$ カタラーゼは $55 \mathrm{kDa}$ カタラーゼの前駆体であることが 判明した(7).

以上述べたことから, カボチャ種子子葉の緑化過程に おいて観察されたカタラーゼ分子の比活性の減少は, 不 活性型であるカタラーゼ前駆体 (59kDa カタラーゼ) の 増加によることは明らかである. したがって, 不活性型 $59 \mathrm{kDa}$ カタラーゼから活性型 $55 \mathrm{kDa}$ カタラーゼへの変 換が，光照射により抑制される可能性が示惨される(7). 事実, その後の研究により, 緑化過程におけるカタラー ゼ活性の減少は活性型の $55 \mathrm{kDa}$ カタラーゼ量の減少に よることが実証された(8).

このように, 緑化に伴ら $55 \mathrm{kDa}$ カタラーゼ量の減少 と $59 \mathrm{kDa}$ カタラーゼ量の増加は, マイクロボディの機 


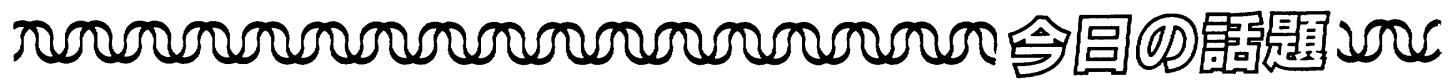

能的変換現象に対応している. したがって, 不活性型カ タラーゼの存在はマイクロボディ変換の制御機構に関す る一つの実例となったのである.

マイクロボディ酵素に関する最近の実験的知見を総合 すると，（i）蛋白質は遊離の ポリソームで合成され, post-translational にマイクロボディ内へ移入される, (ii）その際, マイクロボディ膜の透過にペプチドのプ ロセシングを必要としないとの考え方が支配的であ る(9). カボチャ子葉を用いてマイクロボディ酵素 7 つに ついて生合成の様式を調べたところ，グリオキシゾーム に局在するリンゴ酸シンターゼとクエン酸シンターゼ, 緑葉パーオキシゾームに局在するグリコール酸オキシダ 一ゼとヒドロキシピルビン酸レダクターゼ, 両マイクロ ボディに局在する 3-ヒドロキシアシル CoA デヒドロゲ ナーゼの 5 つの酔素は, いずれも成熟型と同一の分子量 をもつポリペプチドとして合成されてくることが判明し た. 一方, 前述のカタラーゼと, やはり両マイクロボデ イに局在するリンゴ酸デヒドロゲナーゼは, 成熟型より も分子量の大きい前駆体とし、て合成されるとの結果を得 た(10). 同様の実験的結果は, 動物に打いても唯一ラット 肝のチオラーゼについて報告されている(9).このような 例外は，蛋白質のマイクロボディ内への輸送様式を統一 的に解喽する上での困難となっている.けれども, カタ ラーゼで明らかにされた, 前駆体のプロセシングが膜透 過のためではなく酵素の 活性化に必要であるとの考え は, 蛋白質のマイクロボディへの膜輸送様式に統一像を 与えるのみならず，今後のオルガネラ酵素の活性発現様 式を検討する上でも有益なるのとなるかもしれない.

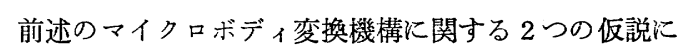
対する明快な解答は, 別の実験的アプローチ,すなわち 免疫組織化学的手法によって得られた. 緑化途中のカボ チャ子葉の超薄切片にプロテイン A-金粒子法を用いて
マイクロボディ酵素の局在性を調べた結果, 同一マイク ロボディ内にグリオキシゾーム酵素のクエン酸シンター ゼと緑葉パーオキシゾーム酵素のグリコール酸オキシダ 一ゼの混在が確認された (投稿中). これは, 両マイクロ ボディはその生合成過程を異にするものではなく，緑化 の過程に拈いて連続的に変換するとする “one-population”モデルを支持する明確な証明にほかならない.

今後の研究においては “one-population”モデルの詳 細な分子機構, たとえば，両マイクロボディ膜に局在す ることが予想されるマイクロボディ蛋白質受容体の差異 や，酵素の輸送拈よび活性発現様式について個々の酵素 ごとに解析していくことが必要であることは改めていら までもない，他方，マイクロボディが外的環境によって 著しくその機能を変えうる点を考虑すれば，単に上述の. 生化学的側面のみならず, 生理学的側面をむ十分に踏ま えて研究する必要があると考えられる.

1) C. De Duve : Sci. Amer., 248(5), 52 (1983).

2) H. Beevers : Ann. Rev. Plant Physiol., 30, 159 (1979).

3) A. H.C. Huang, R. N. Trelease \& T.S. Moore : "Plant Peroxisomes", Academic Press, New York, London, 1983.

4) R. N. Trelease, W. M. Becker, P. J. Gruber \& E. H. Newcomb : Plant Physiol., 48, 461 (1971).

5) T. Kagawa, J. M. Lord \& H. Beevers : Arch. Biochem. Biophys., 167, 45 (1975).

6) J. Yamaguchi \& M. Nishimura : Plant Physiol., 74, 261 (1984).

7) J. Yamaguchi, M. Nishimura \& T. Akazawa : Proc. Natl. Acad. Sci. USA, 81, 4809 (1984).

8）山口淳二, 森 仁志, 西村幹夫, 赤沢 堯 : 生化学, 56, 1038 (1984).

9) S. Miura, M. Mori, M. Takiguchi, M. Tachibana, S. Furuta, S. Miyazawa \& T. Hashimoto : J. Biol. Chem., 259, 6397 (1984).

10) M. Nishimura, J. Yamaguchi, H. Mori \& T. Akazawa; International Cell Biology, pp. 284 (1984).

(山口 淳二, 名古屋大学農学部生化学制御研究施設)

\section{反眴動物の硝酸塩中毒は防除できるか}

\section{饲料添加物質によるルーメン内硝酸代謝制御の可能性}

牛，羊などの反留動物に限って見られるある種の飼料 中毒が “硝酸 (塩) 中毒”として発表されたのは, 今か ら約 40 年前, わが国で初めての症例報告が約 20 年前
のことである. 中毒の原因, 症状, その他関連事項全般 にわたって Wright と Davison ${ }^{(1)}$ の著名な総説があり, 以後の研究や対策に先導的役割を果たし, 最近の 10 年 


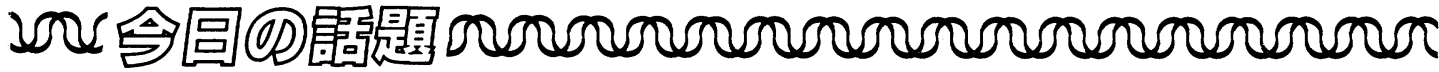

間はこの中毒に関する情報の普及と原因飼料の給与回避 によって，わが国での野外発生例はきわめて少なくなっ たしいし，問題がすべて解決したわけではない，根本 原因が飼料の硝酸塩にあるとしても，中毒発生の経過に は種々の飼養条件が絡んで簡単に割り切れず，消極的な 回避の対策はあっても，積極的な防除の手段は講じられ ない現状である。

牧草，青刈などの畑地に窒素肥料や家畜排泄物を多用 すれば，生産量は当然增加するが，気候温暖なわが国で は，茎葉の硝酸塩含量が上昇することも避けられない， この高硝酸生草 (刈取適期で畭物中 $\mathrm{KNO}_{3}$ として 1 5 \%，10\%を超すこともまれではない）を普通草なみに 動物に多給すると, 可視粘膜の裉色から乳房蒼白, 起立 不能, 呼吸困難へと進み，しばしば死に至る．摂取量少 なく耐過することもあるが，妊娠動物では流産を伴い， 予後不良である.

以上が中毒発生の概略であるが，非反忽動物には無害 の硝酸塩が反留動物に対しては有害である理由として, ルーメン細菌による硝酸塩の還元作用があげられる。す なわち，硝酸からアンモニアに至るルーメン内代謝経路 そおいて，最初に中間体として出現する亜硝酸の生成速 度が亜硝酸自体の還元速度を上回るために、ルーメン内 に亜硝酸が蓄積する．これが吸収されて血中に入るとへ モグロビン $(\mathrm{Hb})$ を酸化・変性してメトへモグロビン (MHb) に変えるから，血液は于ョコレート色になり， 酸素の運搬が妨げられる。亜硝酸の吸収量と連動する $\mathrm{MHb}$ の血中レベルが全 $\mathrm{Hb}$ 中の半量を超えて持続すれ ば, 組織呼吸は著しく阻害され, 動物は致命的状態に陥 る. 吸収量が少ないか，または吸収時間が短ければ, MHb のレベルは低いか，または危険レベルを超えても 速やかに下降し(これは血球内の $\mathrm{MHb}$ 還元酵素系やア スコルビン酸、グルタチオンの存在による)，動物は耐 過する，したがって，硝酸中毒とは $\mathrm{MHb}$ 血症 (methemoglobinemia) であるとするのが，中毒発生機構に 関する一般的見解である.な拉, 治療法としてメチレン ブルーの静注が 有効である（ロイコ型が $\mathrm{MHb}$ を還元 する) が，野外では手遅れのことが多い．

急性の中毒死を招く危険量としては， $\mathrm{KNO}_{3}$ 換算で体 重 $\mathrm{kg}$ 当り $0.5 \sim 1.0 \mathrm{~g}$ と幅をるたせた一応の目安があ
るが，この数値の下限以下でも中毒死する例があり，支 配的要因となるルーメン細菌の硝酸代謝能のほかに，飼 料の組成および物性，反忽，内容物の移動などの影響が まず予想される．なお，野外の発生例が高硝酸生草の給 与初日よりは，3〜4 日目に多発している点が，他の飼 料中毒とは樣相を異にする，その理由を求めるべく， フ イステル付きの緬羊で給与試験を行なったところ，ルー メン液の亚硝酸ピーク濃度は原因草給与初日の最低值か ら経日的に漸増して 4 日目で最高值に達し, 以後はさし て変化しなかった。この時採取したルーメン液から細菌 区分を分離し，in vitro 培養により比較すると，給与前 と給与後の区分では後者の亜硝酸蓄積量が断然高く, 硝 酸から亜硝酸への還元能の増大が認められた。この事央 は, ルーメン細菌の硝酸塩に対する一種の “適応”であ ると推定され，この “適応”によって, 前記の野外発生 状況や $\mathrm{KNO}_{3}$ 反復投与による中毒感受性の増加などは 明快に説明できると主張されだ2。ただし“適応”の中 味が細菌の機能的変化であるか，ないしは菌相の変化が 関わるのかは明らかにされていない，ともあれ，単発的 な投与実験で求められた硝酸塩の極量は，その幅の広狭 とは別に，原因草を継続給与する野外動物に対しては下 方修正が必要である.

高硝酸の生草を危険量給与しても無害であるような中 毒防除法があればそれに越したことはないが，まだ見い だされておらず，硝酸塩の簡易な現場定量法も充分とは いえない（イオン電極法は草種や時期による誤差が大き く，比色法は色調の判定が難しい）から，畜主は時に相 当の不安を感じながら，刚取や放牧をせざるをえない立 場に置かれるであろう，といっても，積極的な防除法の 追究が断念されたわけではない，基本的にはルーメン内

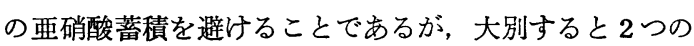
考え方がある.1つは，初めから代謝を阻害して硝酸の まま吸収，排泄させることを狙いとするるの，もう1つ は，这に代謝をできるだけ促進し，特に亚硝酸の還元を 速めてその吸収量, したがって MHb レベルを抑えるこ とを狙いとするるのである.

前者の場合として, 細菌の硝酸還元酵素が Mo を cofactor とする点に着眼し，これに拮抗するWを用いて還 元を阻止する方法が, Waageningen の研究者たちによ 


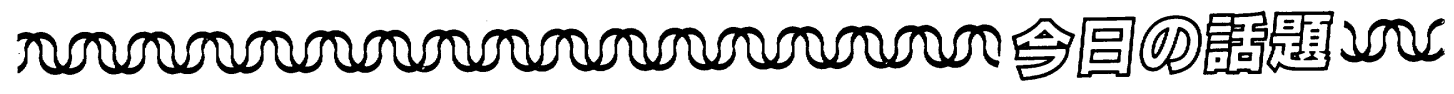

つて試みられ(3), 乳牛の飼料に少量のタングステン酸を 添加, 給与した結果, ルーメン内亜硝酸の蓄積が継続し て抑えられるとの予期通りの成績が示された．Wの毒性 は微弱で乳牛に異常はなく，中毒は防止でさると結論さ れたが，乳汁や排泄物へのWの移行があり，実用化を目 指すならば今後どのように展開させてゆくのかが注目さ れる。

後者の例では, 還元促進のための水素供与体として, 炭水化物の中間代謝で現われる各種の有機酸や単糖を併 用する方法がとり上げられた，in vitro 培養における硝 酸 除いて, ギ酸>水素>グルコース>乳酸>ニハク酸の順 となり(4), 緬羊ルーメン液 in vitro 培養および in vivo 投与実験でも類似の成績が得られ，ギ酸塩と乳酸塩の組 合わせ投与では，ルーメン亜硝酸出現量の 減少と血中 $\mathrm{MHb}$ レベルの低下およびその速やかな復元とが確かめ られた ${ }^{(5)}$. 投与物質は分解されて残らないから，Wより は無難であろらが，もっと有効な組合せや，連続投与時 のルーメン生理, あるいは添加の方法, 経済性など, 前 途にはまだ山が多い。

ルーメン液培養時の 硝酸還元最適 $\mathrm{pH}$ は 7 付近, 覀 硝酸還元は 6 以下であるから，ルーメン内を後者の $\mathrm{pH}$ に保てば西硝酸の蓄積は避けられそうで，これは上述の
2つを併せた考え方に近い，糖質飼料の多給でルーメン $\mathrm{pH}$ は低下寸るから可能性はあるが, $\mathrm{pH}$ の調節が困難 で，行き過ぎるとルーメン過酸症 (rumen acidosis) を 起こし, 動物の食欲減退や種々のルーメントラブルを招 きやすい.

積極的な防除法として 2 つの考え方を述べたが，これ らは要するにルーメン内硝酸代謝の人為的制御の問題で あって，直接には微生物が対象でも，宿主の生理や生産 物への影響が常に付きまとう側面があり，解法の発見を 困難にも，また興味あるものにもしている，ほかに原因 草のサイレージ化, ルーメン原虫の役割, 慢性中毒の有 無などの問題もあるが, 紙数の関係上割愛する. この中 毒についてより詳細を望まれる向きには，最近の総説 ${ }^{(6)}$ があることを付記する。

1) M. J. Wright \& K. L. Davison : Adv. in Agronomy, 16, 197 (1964).

2) 中村 豊, 吉田条二, 中村亮八部, 堀江博文 : 日畜会報, 47, 63 (1976).

3) A. Korzeniowski, J.H. Geurink \& A. Kemp : Neth. J. Agr. Sci., 28, 16 (1980); 29, 37 (1981).

4) G. A. Jones : Can. J. Microbiol., 18, 1783 (1972).

5) Y. Nakamura, J. Yoshida \& R. Nakamura : Proc. Vth World Conf. Anim. Prod., Vol 2, 343 (1983); 中村 豊, 吉田条二, 中村亮八郎 : 日畜会報, 56, 379 (1985)。

6）中村 豊: 宮獣会報, 37, 199, 昭 59 .

(中村亮八郎, 前・茨城大学農学部)

お知らせ

\section{第13回（昭和60年度）研究奨励金 第24回国際会議出席費補助金候補者募集要項}

\section{奖励および補助の対象}

1）研究奖励金：農芸化学諸分野に打ける意欲的な研究. 1 件 1 名としますが，共同研究者を含めてもさしつかえあり ません。

2）国際会議出席費補助金: 海外で開かれる農芸化学諸分野 の国際会議出席希望者. ただし，1986年度 (昭和61年 4 月 1 日から昭和62年 3 月 31 日まで) の国際会議で研究発表を

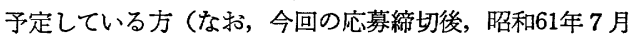
1 日以降に開催される会議に出席を希望される方のため に, 明年 2 月頃再度, 候補者を募集する予定です).

\section{奖励金および補助金の金額}

1) 研究奖励金: 750万円（1 件 50 万円以内，15件）

2) 国際会議出席費補助金：150万円（1 件 30 万円以内, 5 件以内）

\section{応募方法}

所定の用䋊に必要事項を記入のう光，当財団あて御送付くた さい.

※研究桨励金の申請には，申請者の研究内容を熟知している 方 (指導教官・同一専門分野の研究者など) の推薦書 (B 5 判・ 800 字以内）を添付してもけっこうです.

※国際会議出席費補助金の申請には会議での発表論文の要旨 および招請状を添付してくたさい（要旨は英文，和文いず れでもよく，印刷されたものがあればそのコピーでも可).

\section{応募の締切}

昭和 60 年 10 月 31 日 (木) 必着

摆励金および補助金の贈呈

研究奖励金 : 昭和60年12月（予定）

国際会議出席費補助金：昭和61年 1 月以降

応募用紙の請求先および送付先

干 113 東京都文京区弥生2-4-16 学会センタービル内 財団法人 農芸化学研究奖励会 ⓪3 (811) 8789 